\title{
Motorola's global financial supply chain strategy
}

DOI:

10.1109/EMR.2017.7888811

\section{Document Version}

Accepted author manuscript

Link to publication record in Manchester Research Explorer

\section{Citation for published version (APA):}

Blackman, I. D., Holland, C. P., \& Westcott, T. (2017). Motorola's global financial supply chain strategy. IEEE Engineering Management Review, 45(1). https://doi.org/10.1109/EMR.2017.7888811

\section{Published in:}

IEEE Engineering Management Review

\section{Citing this paper}

Please note that where the full-text provided on Manchester Research Explorer is the Author Accepted Manuscript or Proof version this may differ from the final Published version. If citing, it is advised that you check and use the publisher's definitive version.

\section{General rights}

Copyright and moral rights for the publications made accessible in the Research Explorer are retained by the authors and/or other copyright owners and it is a condition of accessing publications that users recognise and abide by the legal requirements associated with these rights.

\section{Takedown policy}

If you believe that this document breaches copyright please refer to the University of Manchester's Takedown Procedures [http://man.ac.uk/04Y6Bo] or contact uml.scholarlycommunications@manchester.ac.uk providing relevant details, so we can investigate your claim.

\section{OPEN ACCESS}




\section{Motorola's global financial supply chain strategy}

\section{Introduction}

Global supply chain management systems rely on financial processes in addition to manufacturing, logistics and marketing activities to coordinate the flow of goods, services and money between separate stages in the supply chain. Financial supply chains are therefore an integral component of supply chains and yet there is very little research that specifically addresses the strategy, implementation and performance of global financial supply chains. Financial processes such as invoices, payments, foreign exchange and banking transactions have received very little attention in the supply chain literature because previous research has tended to focus almost exclusively on the movement of products and services in the supply chain and largely ignores the movement of money and related financial activities.

The literature in this area is only just emerging and is fragmented across academic and business publications. For example, in the academic literature Fairchild (2005) examined the integration of data from financial and product supply chains to explore how companies can increase the efficiency of financial processes by integrating data from physical processes involved in the movement of goods and services with financial processes. Gupta and Dutta (2011) modelled the dynamics of financial supply chains in terms of the flow of money between customers and suppliers. Hofmann (2011) analysed two specific aspects of financial supply chains, risk and supplier financing in the automotive industry.

From a consultancy perspective, Hartley-Urquhart (2006) argued that companies should manage financial supply chains as closely as they manage physical supply chains in order to deal with the inherent complexity and risk of global production systems: as companies operate in a global environment where outsourcing and sourcing arrangements lead to more complex supply chain arrangements and risk management strategies (Chopra and Sohdi, 2004), the financial processes concerned with payments, visibility of the financial process, foreign exchange and risk management need to be much more sophisticated and integrated with the product supply chain. Heuser and Brockwell (2009) addressed similar issues, though from a banking perspective. Their focus was on the treasury management aspects of financial supply chains. In terms of early research originating from industry and management practice, there are parallels with the early development of the supply chain management concept, which Chen and Paulraj (2004) noted was influenced by consultancy practice and industry specific research (e.g. Womack et al., 1991).

The logic of considering financial supply chains as an integral component of supply chains is that the flow of money and related financial and banking services is coordinated by shared financial processes that connect each stage of the supply chain in much the same way that manufacturing and logistics processes manage the flow of products from raw material suppliers through manufacturing, distribution and retail (Camerinelli, 2009). Financial processes are therefore inextricably linked to the supply chain activities defined by Lambert et al. (1998).

There is very little research that directly addresses the subject of financial supply chains that takes an overview of the topic and attempts to define a conceptual framework and illustrate it with significant empirical evidence over a period of time. There is also little consensus 
regarding the formal definition of the financial supply chain concept. The objectives of the research are therefore to define financial supply chains and develop a model that captures the principal elements and characteristics of a financial supply chain. This will then be used as the basis for the analysis of a detailed global case study.

An important element of the research is to understand the strategic evolution of financial supply chains in the context of the manufacturing supply chain over a significant time period, model the performance of a financial supply chain and set out a research agenda for financial supply chains. To start to address the lack of research into financial supply chains, it is necessary to define a framework that captures the core elements of the financial supply chain concept and relates it to the broader literature on manufacturing and logistics. In the next section a review of the literature is presented that forms the basis for the development of a research framework.

\section{Financial Supply Chain Literature}

\subsection{Definition}

The literature that specifically addresses financial supply chains is scant and typically focuses on one specific aspect of the financial supply chain. Finance papers have tended to focus on the technical aspects of financial supply chains (Segev et al., 1998; Lee, 1998) and failed to address the strategic and operations management issues. Other research is also very specialised in nature. For example, researchers have examined the integration of manufacturing and financial data (Fairchild, 2005), the mechanics of electronic payments systems (Chakravorti and Davis, 2004), currency hedging (Hofmann, 2011), financing arrangements (Hofmann, 2005) and technical risk from electronic payments (Johnson, 2008). However, none of these authors provide a conceptual framework or definition of financial supply chains. A broader view has been offered by practising managers - see for example Heuser and Brockwell (2009) who proposed a model of treasury management in the supply chain from a banking perspective but did not provide evidence for its use in practice.

Similar to other rapidly developing subject areas, there is no consensus or agreed definition of the concept. We have therefore derived our definition of financial supply chains from the extant literature on manufacturing supply chains, combined with specific ideas and practice from the emerging financial supply chain literature. There has been extensive research into the formal definition of the supply chain concept. For example, Lambert et al. (1998) based their definition on work undertaken by the global supply chain forum.

"Supply chain management is the integration of key business processes from end user through original suppliers that provides products, services, and information that add value for customers and other stakeholders."

Similarly, Gibson et al. (2005) provided a definition based on their research with the Council for Supply Chain Management Professionals (CSCMP).

"Supply Chain Management encompasses the planning and management of all activities involved in sourcing and procurement, conversion, and all Logistics Management activities. Importantly, it also includes coordination and collaboration with channel partners, which can be suppliers, intermediaries, third party service providers, and customers. In essence, Supply Chain Management integrates supply and demand management within and across companies." 
Mentzer et al. (2008) went on to synthesise these and other definitions to conceptualise supply chain management as:

“... applying analytical tools and frameworks to improve business processes that cross organizational boundaries."

What emerges from these definitions and associated discussions is a broad concept that focuses on the flow of physical goods and services supported by business processes that run along the full extent of the supply chain from the end user to the raw materials suppliers and includes every organisation involved in the design, manufacture, distribution and retail of the product or service. To contribute to the development of research into financial supply chains and to set out the broad scope of the case study, a formal definition of financial supply chains is proposed.

"A financial supply chain is the network of organisations and banks that coordinate the flow of money and financial transactions via financial processes and shared information systems in order to support and enable the flow of goods and services between trading partners in a product supply chain."

To develop this definition of a financial supply chain into a research framework it is necessary to identify the theoretical constructs that capture the essence of the concept. The supply chain management framework proposed by Lambert et al. (1998) is used as the basis for developing a research framework for financial supply chains. These authors identified three, interdependent supply chain dimensions: business processes, management components and network structure. Given that financial supply chains operate in parallel with product supply chains it is reasonable to adapt this framework and use it as the basis for the definition of a financial supply chain.

The business process construct maps directly onto financial supply chains. Management components is concerned with the integration and coordination of business processes. In a financial supply chain, financial business processes are managed through information technology based systems and the sharing of information within and between organisations. To reflect the critical role of information technology combined with management systems, the term 'financial and banking information systems' is used in place of management components. Network structure has been identified as a key feature in the supply chain literature and this concept applies equally to the network structure of organisations and banks involved in the financial supply chain.

In addition to the framework proposed by Lambert et al. (1998), the interaction between the financial and product supply chains is considered and a method for evaluating the performance of a financial supply chain is proposed. Each of the theoretical constructs is defined in more detail in the following sections and used as the basis for the development of a research framework.

\subsection{Interaction between financial and product supply chains}

There is clearly a close and reciprocal relationship between product and financial processes within a supply chain. For example, the globalisation of manufacturing operations and sourcing (Dicken, 2007) requires more sophisticated international payment systems and foreign exchange processes (Holland et al., 1994). Six sigma innovation in a manufacturing 
supply chain (Dasgupta, 2003) places high demands on expected levels of quality in the financial and banking processes. Similarly the development of responsive manufacturing systems that reduce the level of variability of product flows from the supplier to the customer and cooperatively manage risk and product logistics (Manuj and Mentzer, 2008) should be accompanied by financial supply chain strategies that reduce the variability of payment flows and foreign exchange risk from the customer to the supplier, and centralise treasury management and the purchasing of banking services (Chakravorti and Davis, 2004).

\subsection{Financial business processes}

Cooper et al. (1997) identified the crucial importance of business processes in manufacturing supply chain management and that business processes run throughout the supply chain and connect separately owned companies. This is also true for financial processes. The financial business process is defined as the set of activities involved in the coordination of financial transactions within and between separate companies that comprise a manufacturing supply chain and their banking partners. This could include, for example, invoices, domestic and international payments, foreign exchange transactions and remittance advice. In general financial business processes operate in tandem with manufacturing and logistics processes because typically money flows mirror product flows in a supply chain.

\subsection{Financial and banking information systems}

Multinational organisations have gained huge benefits from the integration of management processes within their organisations through the use of Enterprise Resource Planning (ERP) systems that have been accompanied by the development of shared information systems along the supply chain, either simple Electronic Data Interchange (EDI) systems (Scott Morton, 1991; Holland et al. 1992) or more sophisticated electronic business standards such as RosettaNet and the Internet (Segev et al., 1997, 1998; Lancioni et al., 2000). The importance of shared information amongst members of the supply chain to managing logistics is also well documented - for example, see Lee and Billington (1992), Lee et al. (2000). The important point to note here is that the business processes in the supply chain are enabled and connected by information systems, and this is also true for financial processes. In addition to transactional data from internal enterprise and e-commerce systems, financial processes also utilise banking systems that have been designed specifically to manage interorganisational and international financial transactions such as payments.

\subsection{Financial network structure}

Financial network structure is defined as the organisational arrangement of business relationships that connect the focal organisation with its customers, suppliers and banks through multiple tiers of the supply chain. These organisations facilitate financial activities such as the international movement of funds, foreign exchange and the integration of financial processes with the movement of goods and services through the manufacturing supply chain. The banks also carry out related services such as cash management and financial risk management associated with international trade. The mapping out and description of financial network structures is an important contribution to defining, modelling and improving our understanding of how such systems work. However, there is very little theoretical or empirical research in this area and previous published work has tended to focus on just one aspect of financial supply chains such as the banking systems (e.g. Heuser and Brockwell, 2009) or viewed the finance system simply as a support function within a focal firm (Lambert and Cooper, 2000). 


\subsection{Financial supply chain performance}

There is a diversity of approaches and different frameworks to measure the performance of supply chains, taking into account financial and non-financial measurements, operational performance, strategic performance and high-level measures of overall firm performance such as profitability. The measurement of operational performance, typically centred on manufacturing and logistics processes such as order cycles, asset management and stock turnover, is well documented - for example, see Beamon (1999) and Gunasekaran et al. (2004). Other research has attempted to link supply chain management to overall strategy and firm performance - for example, see Frohlich and Westbrook (2001) on the relationship between supply chain integration strategies and performance, Johnson and Templar (2011) for an empirical analysis of the impact of supply chain strategy on cash generation and asset efficiency, and Ellinger et al. (2011) for an analysis of the relationship between supply chain management and firm performance.

To measure financial supply chain performance, the framework proposed by Gunasekaran et al. (2001) to measure the performance of (product) supply chains is adapted to generate three main performance areas: operational/tactical, quality and strategic. The advantages of using this rather broad framework are that it allows the researchers scope to examine the performance characteristics without being overly prescriptive at this relatively early stage of theory development concerning financial supply chains. In the context of financial supply chains, the operational/tactical performance includes measurements such as reduction in international payments from offsetting, efficiency of the foreign exchange process, the leadtime for the payment cycle within the banking system and the reduction of variability of customer-supplier settlement dates. Six sigma quality measurement concepts from manufacturing map directly onto financial processes, for example to measure the quality of payment and foreign exchange transactions. Examples of strategic outcomes from a financial supply chain are increased cohesion in the global financial supply chain and the development of a global payment factory.

\subsection{Research framework}

The research framework (see Figure 1) is composed of the individual constructs discussed above and the relationships between the constructs are based on an adaptation and extension of the supply chain model proposed by Lambert et al. (1998).

\section{(INSERT FIGURE 1 ABOUT HERE)}

The financial supply chain strategy is logically related to the manufacturing and logistics supply chain strategy and this is captured in the model by the interdependence between the financial supply chain strategy and the manufacturing and logistics supply chain strategy (Heuser and Brockwell, 2009). There is a two-way influence where the manufacturing activities place demands on the financial systems, and in turn the financial activities enable the functioning and operation of the manufacturing supply chain. This means that changes in the product supply chain such as new suppliers, increased globalisation of operations and new commercial arrangements (Levitt, 1983; Dicken, 2007) place demands on the financial supply chain. Similarly, new capabilities in the financial systems such as certainty of payment on a specific future date, guaranteed in a local currency and at a fixed exchange rate may enable better trading relationships.

The financial supply chain strategy is an adaptation of the supply chain model proposed by Lambert et al. (1998) and is defined by the set of inter-related theoretical constructs: financial 
business processes, financial and banking information systems, and financial network structure. The performance of the financial supply chain is defined in terms of the quality of operations measured by six sigma techniques, financial operational benefits such as reduced cash balances and better foreign exchange rates, and strategic outcomes such as the development of a global payments factory. The important aspect of performance is that it should be measured dynamically and related to the evolution of the financial supply chain strategy in order to develop a better understanding of how changes in the financial supply chain strategy are empirically related to performance. To understand how the model operates in practice it is applied in a global setting and the methodology and data collection are described in the next section.

\section{Research Methodology and Data Collection}

The case study method was chosen because it enabled new theory development concerning financial supply chain strategy related to information systems and operational performance measures, including six sigma, and it allowed the researchers to uncover aspects and interrelationships of complex phenomena in an organisational setting (Yin, 2009). There is a strong tradition of using case study research to study operations management (McCutcheon and Meredith, 1993) and information systems in practice (Benbasat et al., 1987; Klein and Myers, 1999), and it has been shown to be an effective methodology to evaluate the role and impact of information systems within an organisational context.

The topic of financial supply chains is a relatively new one and in terms of the choice of organisation, the research logic is that case data from an advanced, leading financial supply chain is more likely to yield interesting and insightful results about the definition, evolution, performance and future development of financial supply chains than research into a traditional company with a less advanced strategy. Previous research into Motorola has identified it as a leading company in terms of its global approach to supply chain management (Cederlund et al., 2007; Blanchard, 2010).

The choice of a single case study naturally raises questions about the generalizability of the findings. Yin (2009) emphasises the importance of analytic (rather than statistical) generalization of case study research, where the results and conclusions are generalised to a theory rather than a population. The explanation of our choice of a single case study of a financial supply chain is based on the rationale proposed by Yin (2009), specifically unique, revelatory and longitudinal case studies. The Motorola case study can be considered unique in that there is no similar detailed case study of a global financial supply chain. It could also be argued that the case is revelatory in that the strategy and operational details, including longitudinal performance data, have been inaccessible to researchers in the past. The research is longitudinal, and over an exceptionally long period of time. This enabled the researchers to relate changes in strategy to changes in performance, and start to develop a more explanatory interpretation of the case data.

In addition to these aspects of case choice, it is worth noting that the results effectively apply to a network of companies, notably hundreds of Motorola's suppliers, distributors and customers, and also to the myriad of banks who provide finance and payment systems to Motorola's suppliers, which are in addition to Motorola's bank partners, the Dutch bank, ABN AMRO, which is part of Royal Bank of Scotland (RBS) group and J.P. Morgan. This is an aspect of case research that is of significant importance in improving our understanding of supply chain phenomena using case methods (Seuring, 2008). 
Longitudinal data collection poses certain practical difficulties and issues, not least ensuring the validity and consistency of data. The first point to note is that the theory framework is based on theoretical constructs from the supply chain literature, which increases our confidence in the validity of the constructs. It also provides a structure for the data collection and analysis, whilst retaining flexibility to develop and expand on the constructs through an iterative process that is an inherent part of case research (Eisenhardt, 1989). For the data collection process, the researchers benefited considerably from the fact that during the time period covered by the research, there were only two senior managers in charge of the financial supply chain. This meant that the researchers gained access to individuals with a considerable overview not only of the current systems and strategies, but also of their historical evolution and change.

A major part of the data collection and analysis concerns the operational details and mechanics of how financial supply chains are constructed and perform. The operational details and plans of the financial supply chain are described and recorded in great detail in internal management reports. Similarly the performance of the financial supply chain is tracked on computerised systems as a matter of course as part of Motorola's continuous quality improvement strategy. The multiple sources of data from key informants, management records and operational performance data taken directly from internal systems enabled the researchers to triangulate data to build the timeline of key events and also to dynamically model the operational performance based on data taken directly from computerised systems.

Case study research is often associated with extensive use of qualitative interview data. Whilst interview data with key informants provided invaluable insights into the logic, operation and implementation of the financial systems, nearly all of the performance data is based on transactional data on which statistical analyses can be conducted such as plotting six sigma quality levels over time, or more straightforward plotting of growth and trend analysis in areas such as foreign exchange and payment volumes. In addition, the interview data was corroborated with internal management reports and records pertaining to key events and projects in the strategy timeline. The researchers therefore utilised the organisational memory comprised of key informants, internal reports and the Management Information Systems (MIS) used to track the operational efficiency and quality performance of the financial supply chain. In addition to the internal perspective, data were also collected from Motorola's main bank partners.

The relatively broad performance framework made it is possible to measure performance based on a range of operational data and statistical quality results, combined with qualitative analysis of the strategic outcomes and major events in the strategy evolution as described by key informants within Motorola and its principal bank partners ABN AMRO and J.P. Morgan. Six sigma techniques have been an important methodology to measure the performance of manufacturing systems and supply chains (Linderman et al., 2003; Kwak and Anbari, 2006). A novel aspect of this research is to measure the quality of the financial payment systems using six sigma in a dynamic context and relate changes in the performance to key strategic events in the design and management of Motorola's supply chain. 


\section{Case Data: The Formation and Evolution of Motorola's Financial Supply Chain Strategy}

\subsection{Introduction}

This case study describes the development and evolution of Motorola's global financial supply chain strategy over the period 1976-2010. Motorola has played an iconic role in the development of mobile and wireless communication products in the U.S. and globally. Since its inception, it has launched a series of innovative and technology-leading devices starting with mobile radios in the 1930 s through to web 2.0 phones and services. In addition to its technology, other defining features of the company include its international outlook, its leading role in the implementation and continued development of the six sigma framework and its information systems infrastructure, which enable it to manage geographically disparate manufacturing and financial entities on a global scale (Blackburn and Rosen, 1993; Marquardt and Reynolds, 1994). This paper builds on an earlier case study of Motorola and Citibank (Holland et al., 1994), by extending the timeframe from 1993 to 2010, which provides a unique opportunity to illustrate how long-term changes in global systems and strategies are implemented in practice, and how their performance can be measured and evaluated.

The traditional financial process introduces uncertainty into the supply chain. A powerful customer will typically demand that the price of an international transaction is agreed in its preferred currency. As foreign exchange rates often fluctuate between the time of the sale and when the payment is received, the supplier is exposed to a foreign exchange risk that is not realised until the completion of the transaction. It is also common for large organisations to delay payment beyond the agreed credit period. Another problem for the suppliers is the uncertainty about the exact payment date because of the operational inefficiencies of the customer's financial processes and the additional delays introduced by the banks in the payment process. The delay and uncertainty about future payment receipts increases the financing cost for the suppliers because they must hold higher cash balances to support working capital requirements. Certainty in the payment date for a specific transaction allows the supplier to arrange cheaper sources of finance and operate a leaner cash management strategy. Motorola appreciated and realised these issues very early on and built a global netting system that improved both its internal cash management and its shared financial processes with suppliers.

\subsection{Financial business processes}

The original cash management system connected over one hundred Motorola entities worldwide through a centralised netting system based in London. The system reduced the amount of foreign exchange that needed to be converted and the number of payments between Motorola's operations. Each Motorola operation would enter its payment instructions on a weekly basis. The payments consisted of inter-company payments, for example between Motorola U.S. and Motorola Germany, and payments between Motorola companies and their external suppliers. The system then carried out a defined set of business processes:

1. Offset payments and receivables within Motorola to reduce the total payments volume internally.

2. Net off the foreign exchange by matching international payments between all of Motorola's companies and their suppliers to reduce the volume of weekly foreign exchange 
deals required. So, for example, if Motorola U.S. is making a payment of $€ 200,000$ to a European supplier, and Motorola France is making a U.S. dollar payment of $\$ 230,000$ to an American supplier, then the two payments can be matched to reduce the actual amount of foreign exchange required. This is achieved by making the dollars in the U.S. subsidiary available to Motorola France, and vice versa. This is a simple dyadic example, and the actual system was much more complex because it matched international payments across the whole group of companies in a wide range of currencies.

3. An electronic file of payments was forwarded to Citibank, their global bank partner. Motorola sent remittance advices directly to suppliers so that they would know the exact payment date.

\subsection{The imperative for strategic change}

By 1993, Motorola had established a worldwide netting system that provided a mechanism for coordinating almost $\$ 5$ billion of global payments between separate Motorola operating companies, and with external suppliers. Significant cost savings were being achieved in the areas of international bank payments, foreign exchange and operating savings gained from simplification and centralisation of the treasury management function. However, there were significant operational and human resources issues that needed to be addressed in order to develop the system further and fully exploit its strategic potential. The main operational problem that required immediate attention was the quality of supplier data that enabled the payment and remittance advice processes.

\subsection{Six sigma quality measure of financial processes}

Any inaccurate or incomplete data on suppliers resulted in the payment being rejected by the electronic system and in its place a cheque was issued. However, this led to further problems if the beneficiary details were inaccurate and of the 70,000 payments made in 1993, several hundred failed each month or were delayed and required additional work. The relatively small number of staff in the treasury department who had experience of how the netting system worked also meant that the company was over-reliant on key individuals for specific knowledge. This exacerbated operational difficulties and also made it more difficult to understand the root causes of payment errors.

The principal method used to tackle the operational problems was the application of the manufacturing statistical process control method, six sigma. The objective of six sigma was to eliminate defects in the manufacturing process. Motorola originally developed the technique in 1981 and reaped significant rewards (Blackburn and Rosen, 1993; Marquardt and Reynolds, 1994). Motorola has also been the recipient of the coveted Malcolm Baldrige quality award based on its innovation and application of these techniques in manufacturing (Garvin, 1991). However, the use of these techniques in a finance function was a new venture, and it took considerable effort, training and persistence to make it work. The results from the application of six sigma to global payments are shown in Figure 2 below. 


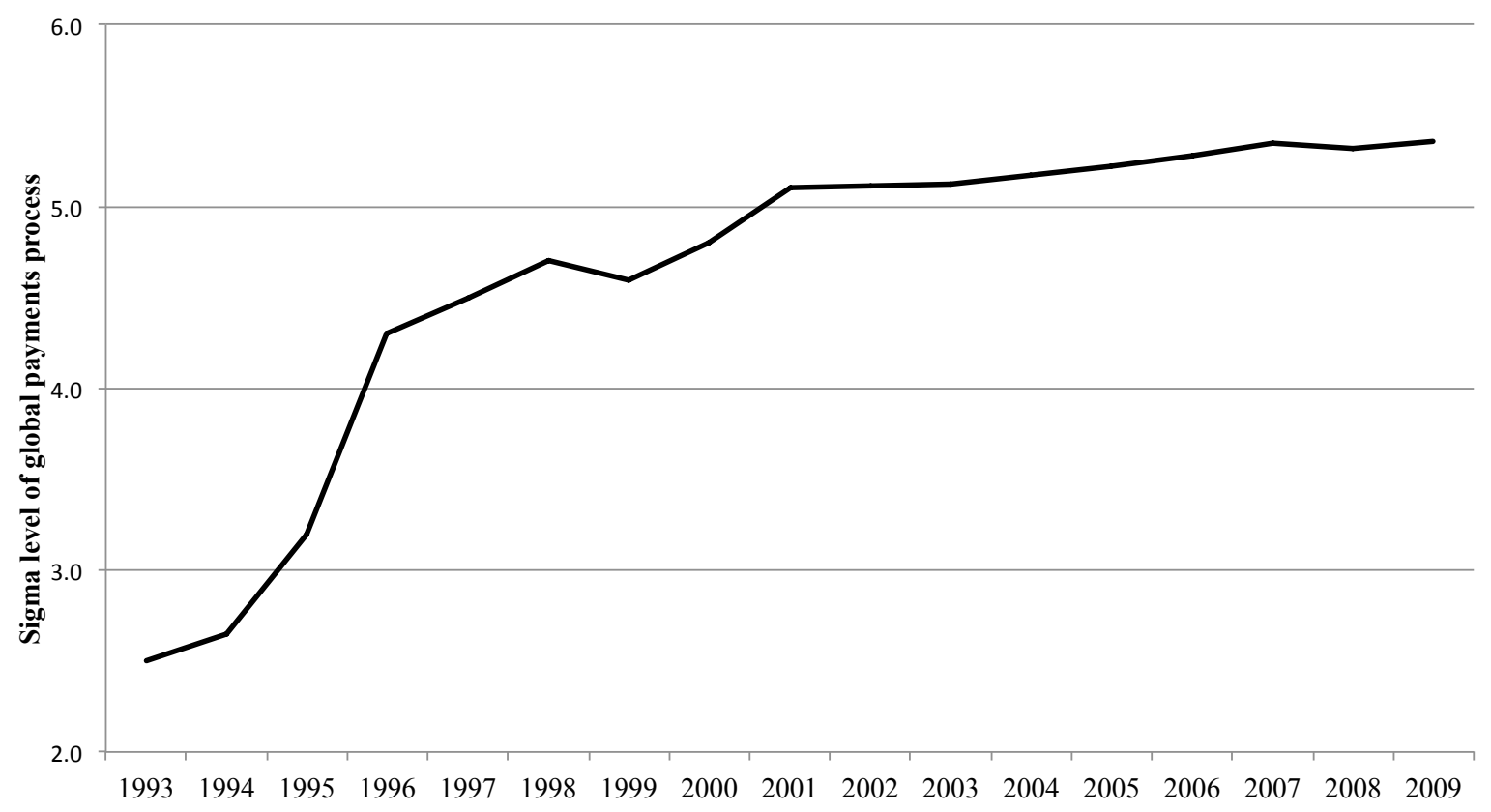

Figure 2. Performance quality of global payments process 1993-2009 using six sigma Source: Motorola payments quality report

To give an idea of the scale and complexity of the operations, the total volume of supplier payments rose from around 70,000 per annum in 1993 to almost 100,000 in 1998 with an average payment value of $\$ 62,000$. Payments between Motorola operating companies rose from 10,000 to 21,000 over the same time period with an average value of $\$ 715,000$.

In terms of actual payments affected, a 3 sigma level equated to problems with around $7 \%$ of total payments so in 1995 there was some type of operational problem with almost 6,000 payments out of a total of 92,000 . The issue was that rejected payments had to be re-inputted to the netting system in time to complete the process. Operational issues at the bank also introduced error rates as high as $20 \%$. It can be seen that the initial improvements from 1993 to 1998 were significant. By 1998, the sigma level had risen to 4.7. The main factor that helps explain this rapid improvement was the increased focus on quality processes within the treasury function and the operating companies, particularly on measuring, improving and controlling the accuracy and completeness of bank data for suppliers. To improve the quality of the process, errors had to be corrected at their source, within the operating company's information system. Rather than the treasury making the corrections the cash was refunded to the operating units until the details were checked for the next cycle. Naming and shaming the business units with the worst quality issues also applied peer pressure.

\subsection{Financial and banking information systems}

The catalyst for further significant improvement over the period 1999-2001 was the introduction of a global Oracle Enterprise Resource Planning (ERP) system, which standardised business processes worldwide. This led directly to an improvement in the consistency of the data originating from the manufacturing systems. The slight dip in 19981999 is explained by the fact that this was a transition period during which the Oracle systems were introduced. In 2005 the co-location of the banking systems, in China, with the internal production management systems was a logical development because the payment instructions are initiated by production and supply chain management activities. Production 
management and banking processes use common data and the close integration of the information systems further increased the accuracy and timeliness of this data. There were continuous improvements between 2005 and 2010 when it reached a point where further improvements would yield only minimal benefits because the number of payment failures per month was very small, that is, the quality performance of 5.4 sigma equates to less than 10 errors per month. These errors could be resolved relatively quickly and easily using manual processes.

\subsection{Growth and evolution of the cash management strategy}

The growth pattern in payment volumes is shown in Figure 3.

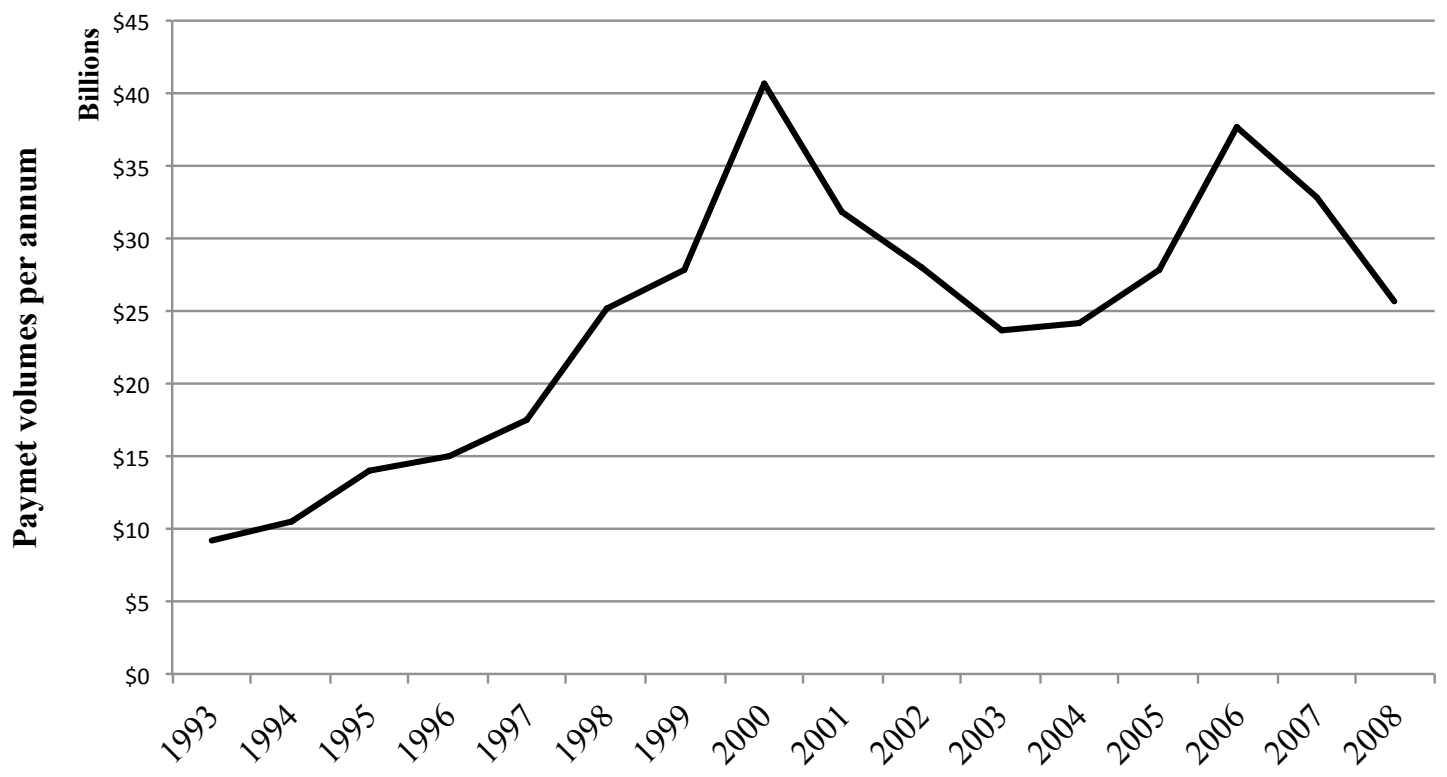

Figure 3. Motorola's payment volumes 1993-2008

Source: Motorola payment systems report

There was steady growth in payment volumes over the period 1993-2000 and the peak coincided with the dot-com bubble. In 2001, Motorola sold its government and defence business to General Dynamics, and in 2004, its semiconductor division was demerged and set up as an autonomous company, Freescale Semiconductors. In 2006, the automotive division was sold to Continental AG. The very high volume of payments in both value and number of payments demonstrates the scale and complexity of Motorola's financial supply chain. From the perspective of the treasury function, an overview of the evolution of Motorola's financial supply chain strategy and performance results for the period 1976-2010 is shown in Table 1.

\section{(INSERT TABLE 1 ABOUT HERE)}

The initial formation of the centralised treasury management function was made possible by Motorola's global information technology infrastructure. Global information systems enabled the implementation of global financial processes and structures. Improvements in technology, in particular the development of standardised manufacturing systems such as SAP and Oracle, coupled with standardised bank services for payments and foreign exchange, have enabled Motorola to more closely integrate its manufacturing and financial supply chains based on common transactional and supplier data. Increasing levels of automation have also led to scale economies that are reflected in the lower unit costs for processes such as foreign exchange transactions and international payments. 
The organisational scope of the financial supply chain system has developed from an internally focused approach to one that now encompasses customers, suppliers, Motorola's bank partners and suppliers' banks. This suggests the emergence of an integrated supply chain strategy that will be able to optimise financial processes at a supply chain level based on cooperation and shared systems rather than trying to maximise the performance of just the focal organisation operating in an adversarial manner.

The strategy evolution is characterised by a relatively small number of significant changes that were accompanied by major re-engineering of financial processes, information systems and network structure, for example the development of a payment factory in China and the outsourcing of the netting system to ABN AMRO. In addition, incremental changes were made to existing systems within a six sigma philosophy and these are reflected in the quality improvements to the major financial processes.

\subsection{Financial network structure}

The current financial network structure that details the organisational and banking arrangements for Motorola's global cash management system is shown in Figure 4. The Oracle ERP system connects Motorola entities worldwide into a single system for the manufacturing supply chain and provides global transactional data to the financial supply chain, banking systems and treasury function. The initiation of supplier payments originates from the Oracle production management system and payment instructions are sent to the global netting system. In the original system, Motorola used a bespoke, internally developed netting system but this was replaced by an outsourced solution in 2005 , provided by ABN AMRO bank, which is now part of Royal Bank of Scotland (RBS).

\section{(INSERT FIGURE 4 ABOUT HERE)}

The netting system collects all of the global payment instructions and offsets the value of payments between Motorola companies, and then nets off the foreign exchange payments in order to reduce the spot foreign exchange requirements. The netting system handled $\$ 20$ billion of payments in 2009. Netting reduced the foreign exchange requirements to $\$ 3$ billion - the netted foreign exchange as a percentage of total international payments over time is shown in Figure 5. 


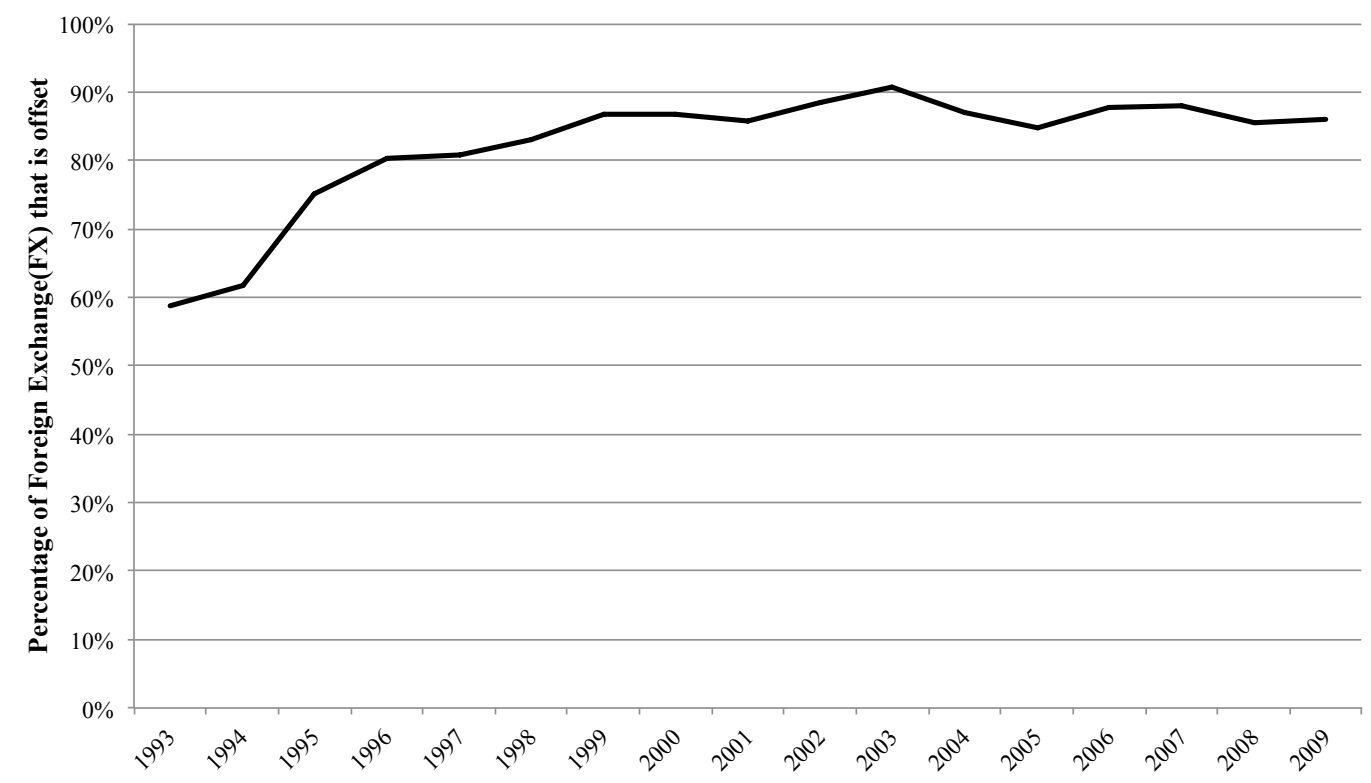

Figure 5. Motorola's netted foreign exchange as a percentage of total payments 19932009

Source: Motorola treasury management report

The volume of foreign exchange payments that are netted against each other has risen from $60 \%$ in 1993 to around $85 \%$ in 2009 . While Motorola had developed a very efficient system to manage the conversion of foreign exchange and process payments, the issue of the foreign exchange risk between the point at which the purchase was made and the settlement at a later time (typically 2-3 months between the purchase order and invoice settlement) remained. To limit the exposure to adverse foreign exchange movements, Motorola uses transactional level data taken directly from its manufacturing systems and hedges against net foreign exposure on a bi-monthly time period. This is a concrete example of a risk management strategy to protect smaller suppliers identified by Hofmann (2011). This practice is an example of an innovation in the financial supply chain that illustrates the potential of moving closer towards the real-time settlement of financial transactions between customers and suppliers in a supply chain context. It has the potential for substantially reducing financial supply chain risk, and also for reducing costs for the supply chain as a whole because it reduces the required level of cash balances in both customer and supplier organisations.

\section{Case Discussion and Comparison with Theory}

\subsection{Interdependency between manufacturing and financial supply chains}

The case data clearly illustrates the interdependency of the financial supply chain and the manufacturing supply chain and shows that it is only possible to build a sophisticated global treasury management and payments system in tandem with a global production network, because the financial system uses core supply chain data to support its business processes. For example, purchase order information must be extracted from the enterprise systems used by Motorola entities worldwide, which each use a common version of the same global ERP system. This enabled the treasury function to exploit the availability of global supply chain management data and to set up centralised payments and treasury functions. The critical role of information technology to enable innovation in the financial supply chain is comparable to 
research by Dehning et al. (2007) who demonstrated the positive effects of information technology on the performance of manufacturing supply chains. The interdependency between manufacturing and financial supply chains also makes strategic changes more complex. This partly explains the long time-scales involved in the implementation of standardised financial processes based on automated systems.

\subsection{Financial business processes}

The internal operational processes developed by Motorola's global treasury function are examples of best practice in the treasury management function. The strategic innovation lies in the use of the centralised treasury function to manage supplier payments and also to collect funds from customers. The collection of funds and the initiation of payments is a high value and high volume transaction process. It is therefore vital to minimise errors and this is the main reason that Motorola applies quality management strategies, including six sigma, to its financial supply chain as well as to its manufacturing supply chain (Marquardt and Reynolds, 1994). The design of automated systems based on standardised financial processes is important because it enables high levels of quality in a high volume transaction environment. It therefore reduces the administrative and banking costs, and also enables a much more refined and focused approach to strategies such as Just-In-Time (JIT) payments than would otherwise be possible.

\subsection{Financial and banking information systems}

Both the manufacturing and financial supply chains rely on a global information system within Motorola comprising Oracle and SAP solutions, and shared information systems and business processes with supply chain partners that utilise business to business exchange of electronic data. The importance of information technology to the operations of the system was demonstrated when the old netting system was no longer available in 2004 - the problem needed to be resolved quickly and a solution was reached by outsourcing the netting system to ABN AMRO. Motorola has maintained a focus on integrating its suppliers into the financial supply chain in the same way that operational improvements in the manufacturing supply chain have been achieved by sharing systems and business processes across organisational boundaries. An important outcome of this case is that suppliers gain much better information on international payments, foreign exchange and banking data in much the same way that Motorola has visibility of future product flows from its suppliers into its manufacturing operations. This is the financial equivalent of reduction in variability between supply chain partners to reduce operational risk, as identified by Manuj and Mentzer (2008).

\subsection{Financial network structure}

An important aspect of Motorola's financial supply chain strategy has been to concentrate its banking businesses with sole bank partners for global netting and payments respectively. ABN AMRO manages the global netting system and J.P. Morgan operates the global payments network. Both of these banking processes are globally dispersed and of strategic importance, and therefore require stability in the financial processes and information systems in order to achieve high levels of operational performance. In contrast, foreign exchange is more straightforward and is much more centralised. Here, the bank partnership approach is to use a defined network of strategic partner banks that ensures active competition in foreign exchange rates whilst maintaining high levels of quality in terms of operational performance.

The bank partnership strategy closely mirrors Motorola's manufacturing ethos where the requirement for high quality means that it typically works with sole or dual supply arrangements for specific products. The mapping out of network structures is an important 
descriptive and analytical tool in product supply chains (Lambert and Cooper, 2000) and has also been identified as an important component of case research studies into supply chains by Seuring (2008). The empirical description of the network and its operation extends the descriptions of financial supply chains in the literature (e.g. Hartley-Urquhart, 2006) by describing the implementation process and measuring the performance outcomes from the perspective of the focal organisation and its suppliers.

The scale of Motorola's global banking requirements makes it a valuable customer. This enabled Motorola to negotiate tailored services to meet specific needs as well as competitive prices. The operational performance of the financial supply chain is tracked and monitored closely, and banks must work with Motorola in a cooperative manner to achieve continuous process and quality improvements, and respond quickly to operational problems. Again, this type of relationship is common with its manufacturing partners, and similar quality control systems are being used to manage the financial processes.

\subsection{Financial supply chain performance}

A summary of the performance results and strategic outcomes of the case study is shown in Table 2. The overall performance results can be grouped quite naturally to the adapted framework from Gunasekaran et al. (2001) and the longitudinal data on six sigma quality provide an exceptional overview of long-term performance related to strategic changes in the financial supply chain that is very different to the typical snapshot or short time period that is common in the literature (Seuring, 2008).

\section{Table 2. Summary of performance outcomes for the financial supply chain}

Quality of business processes expressed in six sigma
- $\begin{aligned} & \text { Improved internal financial processes for payments and foreign exchange } \\ & \text { international payments }\end{aligned}$
- $\begin{aligned} & \text { Operational benefits } \\ & \text { Reduced payment volumes between international subsidiaries }\end{aligned}$
- $\begin{aligned} & \text { Administrative savings for managing payments and treasury functions on a } \\ & \text { global basis arising from lower error rates in the financial processes }\end{aligned}$
- $\begin{aligned} & \text { Foreign exchange hedging linked to the purchase order } \\ & \text { Improved decision support for negotiating banking transaction charges for } \\ & \text { payments and foreign exchange deals centrally }\end{aligned}$
Improved cash flows to suppliers because of more frequent and timely payments
- $\begin{aligned} & \text { Ability to manage financial supply chain globally } \\ & \text { - Strengthening of relationships with manufacturing partners and customers } \\ & \text { Closer alignment of finance processes with physical supply chain so that cash } \\ & \text { flows mirror product flows } \\ & \text { Management of the financial supply chain as a cohesive unit leading to network } \\ & \text { benefits that are shared between Motorola and its suppliers }\end{aligned}$

The integration of financial processes along the supply chain is a logical and natural development that builds on the emergence of global integrated supply chains designed around logistics and manufacturing systems (Coe et al., 2008). Motorola's willingness to share the financial and operational benefits of an integrated payments system with its suppliers is 
further evidence that the supply chain is the unit of analysis to focus on in order to understand how global trading networks function and operate, and is an empirical example of how information is shared within a financial supply chain in much the same way as manufacturing and logistics data is shared between stages of a supply chain (e.g. Lee et al., 2000).

\subsection{Nature of the strategic change process}

Whilst the nature of the change process was not a primary objective of the research, some brief comments and observations are made in order to contextualise the description of the strategy evolution and performance. Clear strategic intent resulted in changes to the business processes and financial network structure that required information systems to enable and implement the revised strategy. The business process and network structure changes occurred on two levels, within Motorola and to the financial supply chain as a whole.

The human element of implementing a global system should not be forgotten. Slone (2004) describes the importance of leadership and talent within the senior management team, in addition to the innovative use of technologies and processes in the implementation of supply chain strategies. This is also true in the case of Motorola. The stability of the management of the project greatly helped the process of reaching agreements with the finance functions within Motorola and also between Motorola and its manufacturing and banking partners. In the time period 1988-2012 there have been just two treasury directors involved in the formulation and implementation of Motorola's global financial supply chain strategy. Not a little tenacity was required to maintain the support to improve the financial processes throughout this time period. It was also important that treasury management was able to build relationships with other functional areas within the business, especially manufacturing and IT, in order to develop global systems with banks and suppliers. This aspect of the strategic change confirms the importance of functional integration to support strategic change (van Hoek et al., 2008) and also illustrates the important role that senior finance staff can play in making an active contribution to overall strategic direction (Jablonsky, 1999; Jablonsky and Barsky, 2000).

\subsection{Discussion of research framework}

The above discussion regarding the individual components of the research framework and their application to the case data demonstrates the validity of the constructs on an individual basis. Some specific examples from the case data are highlighted that further explain how the individual constructs are related to each other. Firstly the relationships between the constructs within the financial supply chain strategy are considered. Secondly, the relationship between the financial supply chain strategy and the manufacturing and logistics strategy is analysed. Thirdly the link between financial supply chain strategy and performance is evaluated.

Starting with the core of the model, the financial supply chain strategy, the development of new financial information systems infrastructure and EDIFACT standards in 1991 and 1992 had the effect of standardising the financial process for payments. This also enabled the development of a new financial network structure between Motorola, its suppliers and Citibank. This in turn had performance implications because for the first time remittance advice data could be sent electronically to suppliers, who could then take advantage of advance notification of payments. Another example of interdependencies between the constructs is in the financial process for managing foreign exchange exposure. In 1996 a new strategy to manage foreign exchange risk at the level of the purchase order was implemented. It relied on the information systems to provide transactional level manufacturing data that could be integrated with the financial process for hedging foreign exchange. Lastly, the 
change in bank network structure in 1997 that was designed to increase competition between the banks resulted in lower costs to Motorola and increased growth in the electronic payments financial process. The general pattern to all of these examples is that the constructs that comprise the financial supply chain strategy are interdependent - financial business processes drive, and are driven by, financial and banking information systems, and financial network structure.

The demerger of the semiconductor division in 2004 demonstrates the interaction between the manufacturing and logistics supply chain and the financial supply chain. The change in the manufacturing supply chain, the demerger of the semiconductor business, resulted in a change to the financial network structure through a new partnership with ABN AMRO and also to the financial information systems, which were based on an outsourced solution.

The empirical evidence that demonstrates the relationship between financial supply chain strategy and performance is the mapping out of the evolutionary timeline of the financial supply chain strategy and relating key events and strategy changes to performance outcomes. Changes in the financial supply chain strategy can then be related to qualitative improvements in areas such as financial process innovations and better relationships with suppliers and banks, and also to quantitative, operational performance improvements, for example time-series payment volumes and six sigma levels.

\subsection{Contribution of the research}

The main contribution of the research is to identify and analyse the importance of financial supply chains to the supply chain management subject area and to illustrate the concepts with a global case study of Motorola spanning over 30 years. The theoretical and empirical contributions are integrated through a research framework of financial supply chains. The empirical research demonstrates the validity of the individual constructs in the research framework model and also illustrates how they are related and interdependent. An important and significant feature of the case study is the longitudinal analysis of key strategic events and performance. This analysis combines qualitative data, management reports and electronic records of detailed transactional data such as payment volumes and six sigma quality.

A limitation of the study is that it is based on a single, global financial supply chain network, so although it is possible to generalise the findings to a theory of financial supply chains, it does not tell us about the characteristics and features of other global financial supply chains. This presents new research opportunities to explore whether the findings in this study are common to other global networks and to extend the ideas presented in this paper to develop more general models that explain the formation and evolution of financial supply chains in different organisational contexts.

\section{Conclusions}

\subsection{Research framework}

Academic research in supply chain management has tended to focus on manufacturing and logistics and has largely neglected financial supply chains. The lack of previous research in this area is addressed through the proposal of a formal definition for this relatively new topic and a research framework that is based on an adaptation of concepts from the supply chain literature, notably Lambert et al. (1998). 
The research framework has been applied to a detailed, longitudinal case study of Motorola over the period 1976-2010. The case analysis shows that financial supply chains are an integral and strategically important component of supply chains. Motorola's financial supply chain strategy illustrates the nature of the close interdependencies between product and money flows and describes how the financial supply chain has evolved in response to changes in the manufacturing supply chain. In turn, innovations in financial processes have enabled improvements in the management of the overall relationship with customers, suppliers and banks.

The three main theoretical constructs used to define the financial supply chain successfully captured the content and key characteristics of Motorola's strategy in this area. Financial business processes model the activities concerned with the coordination and management of financial transactions between trading partners in a supply chain context. Motorola's information technology infrastructure enabled innovations and improvements to the financial processes because the information systems integrated manufacturing and logistics transactions with financial transactions on a global scale. The potential of this type of approach was identified by Fairchild (2005) though with very little empirical evidence and without the international dimension of this case study. Information technology and systems are as important in financial supply chains as they are in manufacturing supply chains (Dehning et al., 2007). The mapping of the financial network structure was an essential part of the analysis because it uncovered important details concerning shared financial processes, information flows and the inter-organisational relationships that exist between the focal organisation, Motorola, and its customers, suppliers and banks. This type of detailed network structure is relatively uncommon in the literature and is a significant advancement over previous theoretical models in this area (e.g. Gupta and Dutta, 2011).

A performance measurement framework adapted from Gunasekaran et al. (2001) showed that Motorola's development of a global financial supply chain yielded significant operational benefits, for example reduced international payments, lower banking charges, reduced foreign exchange costs and better risk management from hedging foreign exchange. Motorola has been a world-leader in its use of quality frameworks, notably six sigma, and it is has also applied these concepts to measure and evaluate the performance of its financial processes. The quality of financial processes increased dramatically from 2.5 to 5.3 sigma quality level. Significant strategic benefits were also realised, including the ability to manage financial processes on a global scale that matched Motorola's manufacturing capabilities and the ability to manage the financial supply chain as a cohesive unit and achieve network benefits beyond the organisational boundaries of the focal firm.

\subsection{Supply chain management strategy}

The financial supply chain strategy evolution is characterised by incremental improvements, often based on six sigma concepts, punctuated by step-changes in financial business processes, network structure and information systems design. The overwhelming trend is towards a standard financial supply chain model to coordinate international banking and payments throughout the product supply chain. The movement of products and services encapsulated by the manufacturing supply chain is now supported by parallel financial and banking systems. As close collaboration is required between the trading partners within the supply chain to meet customer needs, the movement of funds has evolved to track the movement of goods in a concomitant manner rather than as a distinct and separate management function. 
The case also illustrates how the strategic focus has shifted from attempting to optimise the performance of an individual company to improving the performance of the supply chain as a cohesive unit through shared systems and a collaborative strategy (Holland, 1995). This is reflected by the fact that in addition to the internal benefits to Motorola, suppliers also gain significant benefits in terms of improved visibility of the financial supply chain gained from shared finance systems, certainty in payment terms, improved cash flow, lower administrative costs and improved risk management for currency fluctuations. The supplier benefits in turn generate further intangible benefits to Motorola, for example better cooperation and a willingness of suppliers to adapt in the context of the overall relationship, including flexibility in the management of the manufacturing and logistics. The formation of an integrated supply chain supports the argument that competition takes place between supply chains rather than between individual companies (Horvath, 2001; Christopher, 2005).

\subsection{Future research}

Research into financial supply chains is in its infancy when compared to research into manufacturing supply chains. An agenda for future research opportunities is therefore proposed. The research framework was effective at capturing the principles of financial supply chains but the model could be extended in terms of additional variables, for example the nature of the strategic change process and project management techniques, and also into the nature of the relationships between the variables in the research framework.

Another important area is the detailed modelling of the flow of payments, akin to the modelling of product flows based on shared information between manufacturers and suppliers (Blackman and Holland, 2006; Gupta and Dutta, 2011). What are the benefits to suppliers of receiving advance notification of payments with a certainty that they will receive funding in their own currency on a specific and guaranteed date? How should benefits such as reduced borrowing and foreign exchange requirements be quantified? How will the frequency of payments change in the future as it becomes possible to manage financial exchanges between trading partners at the level of individual items on a purchase order because of lower transactional costs from advances in information technology and banking systems?

In terms of formulating strategy for financial supply chains, moving away from a standard adversarial stance to a cooperative partnership approach with suppliers and banks requires a significant shift in the mind-set of senior finance managers who are typically accustomed to maximising financial benefits within the organisational boundary of their own firm rather than looking to the competitive nature of the supply chain as a whole. However, the strategic benefits such as managing finances on a global scale and better relationships with suppliers, coupled with evidence from previous research that shows supply chain management capabilities are correlated with firm performance (Johnson and Templar, 2011) should encourage finance specialists to work closely with manufacturing and logistics managers to realise the benefits of closer integration across functional areas within the company and along the supply chain. In an economic environment where the availability and cost of bank funding are becoming significant problems, particularly for smaller companies, supply chain financing based on closer financial ties between large organisations and their supply networks becomes an attractive and strategically important opportunity. Empirical research in other global financial supply chains is needed to tackle these types of questions convincingly.

As financial supply chains are managed more closely with the physical flow of goods then it is clear that there will be increased information technology and business process integration 
between finance and other functional areas. Within a company this requires technical and management integration across internal business processes, in particular the ERP and finance/banking systems. What implementation issues are associated with such changes? What prerequisites need to be in place before companies can innovate in their financial processes?

Moving beyond an internal focus and looking at shared business processes along the supply chain raises more challenges and research opportunities. For example what are the likely future developments in inter-organisational financial systems? How important are new electronic communication standards for financial processes and how do they relate to contemporary technology developments in supply chain logistics and production such as RFID and RosettaNet e-commerce?

Lastly, what types of banking arrangements should companies pursue? The supply chain literature has not yet addressed this area and the only commentary is from banking specialists, for example Heuser and Brockwell (2009). The importance of quality and the need to integrate systems very closely would indicate that a partnership approach with a relatively small number of banks is an effective strategy. But will this continue to be the case in the future as the systems become more standardised and it becomes easier to switch relationships with suppliers for standard services such as bank payments? What is the optimal number of suppliers for foreign exchange transactions? This is not such a straightforward question because it involves a range of factors including foreign exchange rates, currency breadth, financial risk and the administrative cost of dealing with multiple partners and quality of operational services.

\section{References}

Beamon, B.M. (1999), "Measuring supply chain performance", International Journal of Operations \& Production Management, Vol. 19 No. 3, pp. 275-292.

Benbasat, I., Goldstein, D.K. and Mead, M. (1987), "The case research strategy in studies of information systems", MIS Quarterly, Vol. 11 No. 3, pp. 369-386.

Blackburn, R. and Rosen, B. (1993), "Total quality and human resources management: Lessons learned from Baldrige award-winning companies", Academy of Management Executive, Vol. 7 No. 3, pp. 49-66.

Blackman, I.D. and Holland, C.P. (2006), "The management of financial supply chains: from adversarial to co-operative strategies", in IFIP International Federation for Information Processing, Vol. 226, Project E-Society: Building Bricks, ed. R. Suomi, R. Cabral, J. Hampe, A. Heikkilä, J. Järveläinen and E. Koskivaara, Springer, Boston, pp. 82-95.

Blanchard, D. (2010), Supply Chain Management Best Practices, 2nd edition, John Wiley \& Sons, Hoboken, NJ, pp. 62-63.

Camerinelli, E. (2009), "Supply chain finance”, Journal of Payments Strategy \& Systems, Vol. 3 No. 2, pp. 114-128.

Cederlund, J.P., Kohli, R., Sherer, S.A. and Yao, Y. (2007), "How Motorola put CPFR into action", Supply Chain Management Review, Vol. 10 No. 7, pp. 28-35. 
Chakravorti, S. and Davis, E. (2004), “An electronic supply chain: will payments follow?" Special Issue, The Federal Reserve Bank of Chicago, Chicago Fed Letter, Number 206a, September, pp.1-4.

Chen, I.J. and Paulraj, A. (2004), "Towards a theory of supply chain management: the constructs and measurements”, Journal of Operations Management, Vol. 22 No. 2, pp. 119-150.

Chopra, S. and Sohdi, M.S. (2004), "Managing risk to avoid supply-chain breakdown", MIT Sloan Management Review, Vol. 46 No. 1, pp. 53-62.

Christopher, M., (2005), Logistics and Supply Chain Management: Ccreating Value-added Networks, FT Prentice Hall, Pearson Education, Harlow.

Coe, N.M., Dicken, P. and Hess, M. (2008), "Global production networks: realizing the potential", Journal of Economic Geography, Vol. 8 No. 3, pp. 271-95.

Cooper, M.C., Lambert, D.M. and Pagh, J.D. (1997), "Supply chain management: more than a new name for logistics", International Journal of Logistics Management, Vol. 8 No. 1, pp. 1-14.

Dasgupta, T. (2003), "Using the six-sigma metric to measure and improve the performance of a supply chain", Total Quality Management and Business Excellence, Vol. 14 No. 3, pp. 355-366.

Dehning, B., Richardson, V.J. and Zmud, R.W. (2007), "The financial performance effects of ITbased supply chain management systems in manufacturing firms", Journal of Operations Management, Vol. 25 No. 4, pp. 806-824.

Dicken, P. (2007), Global Shift: Mapping the Changing Contours of the World Economy, 5th edition, Sage, London.

Eisenhardt, K.M. (1989), "Building theories from case study research", Academy of Management Review, Vol. 14 No. 4, pp. 532-550.

Ellinger, A.E., Natarajarathinam, M., Adams, F., Frank, G., Gray, J., Hofman, D. and O’Marah, K. (2011), "Supply chain management competency and firm financial success", Journal of Business Logistics, Vol. 32 No. 3, pp. 214-226.

Fairchild, A. (2005), "Intelligent matching: integrating efficiencies in the financial supply chain", Supply Chain Management: An International Journal, Vol. 10 No. 4, pp. 244-248.

Frohlich, M.T. and Westbrook, R. (2001), "Arcs of integration: an international study of supply chain strategies", Journal of Operations Management, Vol. 19 No. 2, pp. 185-200.

Garvin, D.A. (1991), "How the Baldrige Award really works", Harvard Business Review, Vol. 69 No. 6, pp. 80-93.

Gibson, B.J., Mentzer, J.T. and Cook, R.L. (2005), "Supply chain management: the pursuit of a consensus definition", Journal of Business Logistics, Vol. 26 No. 2, pp. 17-25.

Gunasekaran, A., Patel, C. and Tirtiroglu, E. (2001), "Performance measures and metrics in a supply chain environment", International Journal of Operations \& Production Management, Vol. 21 No. 1, 
pp. $71-87$.

Gunasekaran, A., Patel, C. and McGaughey, R.E. (2004), "A framework for supply chain performance measurement", International Journal of Production Economics, Vol. 87 No. 3, pp. 333-347.

Gupta, D. and Dutta, K. (2011), "Modeling of financial supply chain", European Journal of Operational Research, Vol. 211 No. 1, pp. 47-56.

Hartley-Urquhart, R. (2006), "Managing the financial supply chain," Supply Chain Management Review, Vol. 10 No. 6, pp. 18-18.

Heuser, J. and Brockwell, J. (2009), Treasury and the Supply Chain: A New Model for Working Capital Management, J.P. Morgan Chase, New York.

Hofmann, E. (2005), "Supply chain finance: some conceptual insights", in Lasch, R. and Janker, C.G. (Eds), Logistik Management - Innovative Logistikkonzepte, Gabler, Wiesbaden, pp. 203-214.

Hofmann, E. (2011), "Natural hedging as a risk prophylaxis and supplier financing instrument in automotive supply chains", Supply Chain Management: An International Journal, Vol. 16 No. 2, pp. $128-141$.

Holland, C.P. (1995), "Cooperative supply chain management: the impact of interorganizational information systems”, Journal of Strategic Information Systems, Vol. 4 No. 2, pp. 117-133.

Holland, C.P., Lockett, A.G. and Blackman, I. (1992), "Planning for electronic data interchange", Strategic Management Journal, Vol. 13 No. 7, pp. 539-550.

Holland, C.P., Lockett, A.G., Richard, J.M. and Blackman, I.D. (1994), "The evolution of a global cash management system", Sloan Management Review, Vol. 36 No. 1, pp. 37-47.

Horvath, L. (2001), "Collaboration: the key to value creation in supply chain management", Supply Chain Management: An International Journal, Vol. 6, No. 5, pp. 205-207.

Jablonsky, S.F. (1999), "Business advocates and corporate cops: core values from fad to fact", Strategic Finance, Vol. 81 No. 5, pp. 50-54.

Jablonsky, S.F. and Barsky, N.P. (2000), “The digital CFO”, Strategic Finance, Vol. 81 No. 12, pp. $52-56$.

Johnson, M.E. (2008), "Information risk of inadvertent disclosure: an analysis of file sharing risk in the financial supply chain", Journal of Management Information Systems, Vol. 25 No. 2, pp. 97-123.

Johnson, M. and Templar, S. (2011), "The relationships between supply chain and firm performance: the development and testing of a unified proxy", International Journal of Physical Distribution \& Logistics Management, Vol. 41 No. 2, pp. 88-103.

Klein, H.K. and Myers, M.D. (1999), "A set of principles for conducting and evaluating interpretive field studies in information systems", MIS Quarterly, Vol. 23 No. 1, pp. 67-93. 
Kwak, Y.H. and Anbari, F.T. (2006), "Benefits, obstacles, and future of six sigma approach", Technovation, Vol. 26 Nos. 5-6, pp. 708-715.

Lambert, D.M. and Cooper, M.C. (2000), "Issues in supply chain management", Industrial Marketing Management, Vol. 29 No. 1, pp. 65-83.

Lambert, D.M., Cooper, M.C. and Pagh, J.D. (1998), "Supply chain management: implementation issues and research opportunities", International Journal of Logistics Management, Vol. 9 No. 2, pp. $1-20$.

Lancioni, R.A., Smith, M.F. and Oliva, T.A. (2000), "The role of the Internet in supply chain management”, Industrial Marketing Management, Vol. 29 No. 1, pp. 45-56.

Lee, H.L. and Billington, C. (1992), "Managing supply chain inventory: pitfalls and opportunities", Sloan Management Review, Vol. 33 No. 3, pp. 65-73.

Lee, H.L., So, K.C. and Tang, C.S. (2000), "The value of information sharing in a two-level supply chain", Management Science, Vol. 46 No. 5, pp. 626-643.

Lee, M.K.O. (1998), "Internet-based financial EDI: towards a theory of its organizational adoption", Computer Networks and ISDN Systems, Vol. 30 Nos. 16-18, pp. 1579-1588.

Levitt, T. (1983), “The globalization of markets”, Harvard Business Review, Vol. 61 No. 3, pp. 92102.

Linderman, K., Schroeder, R.G., Zaheer, S. and Choo, A.S. (2003), "Six Sigma: a goal-theoretic perspective", Journal of Operations Management, Vol. 21 No. 2, pp. 193-203.

Manuj, I, and Mentzer, J.T. (2008), "Global supply chain risk management strategies", International Journal of Distribution and Logistics Management, Vol. 38 No. 3, pp. 192-223.

Marquardt, M.J. and Reynolds, A. (1994), "Motorola: trans-cultural learning and global alliances", in Marquardt, M.J. and Reynolds, A. (Eds), The Global Learning Organization: Gaining Competitive Advantage Through Continuous Learning, Irwin, New York, pp. 213-220.

McCutcheon, D.M. and Meredith, J.R. (1993), "Conducting case study research in operations management”, Journal of Operations Management, Vol. 11 No. 3, pp. 239-256.

Mentzer, J.T., Stank, T.P. and Esper, T.L. (2008), "Supply chain management and its relationship to logistics, marketing, production, and operations management", Journal of Business Logistics, Vol. 29 No. 1, pp. 31-46.

Scott Morton, M.S. (1991), The Corporation of the 1990s: Information Technology and Organizational Transformation, Oxford University Press, New York.

Segev, A., Porra, J. and Roldan, M. (1997), "Internet-based EDI strategy", Decision Support Systems, Vol. 21 No. 3, pp. 157-170.

Segev, A., Porra, J. and Roldan, M. (1998), "Internet security and the case of Bank of America", Communications of the ACM, Vol. 41 No. 10, pp. 81-87. 
Seuring, S.A. (2008), "Assessing the rigor of case study research in supply chain management", Supply Chain Management: An International Journal, Vol. 13 No. 2, pp. 128-137.

Slone, R.E. (2004), "Leading a supply chain turnaround", Harvard Business Review, Vol. 82 No. 10, pp. 114-121.

van Hoek, R., Ellinger, A.E. and Johnson, M. (2008), "Great divides: internal alignment between logistics and peer functions", International Journal of Logistics Management, Vol. 19 No. 2, pp. $110-129$.

Womack, J.P., Jones, D.T. and Roos, D. (1991), The Machine that Changed the World, HarperPerennial, New York.

Yin, R.K. (2009), Case Study Research: Design and Methods, 4th edition, Sage, Thousand Oaks, Calif. 
Table 1. The evolution of Motorola's financial supply chain strategy, 1976-2010

\begin{tabular}{|c|c|c|}
\hline \multicolumn{3}{|c|}{ Evolutionary Timeline of Financial Supply Chain Strategy } \\
\hline Date & Key Events and Changes & Performance Results \\
\hline 1976 & $\begin{array}{l}\text { All payment data were collected in Chicago and } \\
\text { controlled from Geneva. The currency netting system } \\
\text { was implemented. The original system exploited a } \\
\text { COBOL email system that connected all the Motorola } \\
\text { companies and enabled them to share data quickly and } \\
\text { easily. }\end{array}$ & $\begin{array}{l}\text { Reduction of cash flows within the organisation and } \\
\text { the establishment of a simple global system. }\end{array}$ \\
\hline 1988 & $\begin{array}{l}\text { The European treasury management function was } \\
\text { moved to London. Secure electronic links with Citibank } \\
\text { enabled the electronic payments process to be } \\
\text { extended to suppliers. }\end{array}$ & $\begin{array}{l}\text { The skills required to manage an international } \\
\text { treasury were readily available in London. The } \\
\text { treasury was also close to its key banking suppliers. } \\
\text { A significant increase in the scale of the netting } \\
\text { process was achieved. }\end{array}$ \\
\hline 1991 & $\begin{array}{l}\text { The IT infrastructure composed of the global email } \\
\text { system, leased lines and Value-Added-Networks } \\
\text { (VANs) enabled the sharing of data between Motorola, } \\
\text { its bank and its suppliers on a worldwide basis. }\end{array}$ & $\begin{array}{l}\text { Strategic alliance with Citibank developed further } \\
\text { through the use of EDI systems. Option to move to } \\
\text { another supplier retained with the use of an industry } \\
\text { standard for the payment orders. }\end{array}$ \\
\hline 1992 & $\begin{array}{l}\text { Development of EDIFACT standards for supplier } \\
\text { remittance advice. }\end{array}$ & $\begin{array}{l}\text { The process made the payment process more } \\
\text { transparent and enabled the suppliers to easily } \\
\text { identify payment delays. Suppliers received } \\
\text { significant benefits in terms of timely payments and } \\
\text { advanced notification of payment dates from the } \\
\text { electronic remittance advice message. }\end{array}$ \\
\hline 1993 & $\begin{array}{l}\text { The electronic payment system was used for all } \\
\text { payments greater than } \$ 14,000 \text {. Worldwide checks } \\
\text { were used for payments with a value less than } \$ 14,000 \\
\text { and also for payments that did not have sufficient } \\
\text { banking details to be paid electronically. All inter- } \\
\text { company payments within the Motorola group are } \\
\text { electronic payments. }\end{array}$ & $\begin{array}{l}\text { The poor quality of the payment data resulted in a } \\
\text { high level of repairs and delays to higher value } \\
\text { payments combined with the significant use of } \\
\text { checks because of incomplete suppliers' electronic } \\
\text { bank details. }\end{array}$ \\
\hline 1993 & $\begin{array}{l}\text { Introduced the ability to collect payments through the } \\
\text { netting system. Hedging of foreign exchange risk was } \\
\text { based on forecasts and included in the netting cycle. }\end{array}$ & $\begin{array}{l}\text { Centralising the collection of funds increased the } \\
\text { efficiency of the netting process. Motorola reduced } \\
\text { its costs to trade foreign currency. The efficiency of } \\
\text { Motorola's hedging process was increased, which } \\
\text { reduced the level of foreign exchange exposure. }\end{array}$ \\
\hline 1996 & $\begin{array}{l}\text { Started to use purchase order details to improve the } \\
\text { visibility of foreign exchange exposure. The netting } \\
\text { system was used to process the transactions required } \\
\text { to hedge the foreign currency exposure. }\end{array}$ & $\begin{array}{l}\text { Management of the foreign exchange risk was moved } \\
\text { from forecast to real-time data by capturing financial } \\
\text { data when the risk was generated at the time the } \\
\text { purchase order was raised. }\end{array}$ \\
\hline 1997 & $\begin{array}{l}\text { Dutch BV European cash management centre was used } \\
\text { as the in-house bank. The netting system was used to } \\
\text { collect insurance payments on a worldwide basis for } \\
\text { the captive insurer. } \\
\text { To introduce competitive pressures to resolve the } \\
\text { quality issues a multibank payment capability was } \\
\text { developed. Payment files were split between Citibank } \\
\text { and J.P. Morgan. Reduced the lower limit for checks to } \\
\$ 7,000 \text {. }\end{array}$ & $\begin{array}{l}\text { Centralised the management of surplus cash and } \\
\text { short-term funding in Europe. The inclusion of } \\
\text { insurance payments increased the scale of the } \\
\text { netting system and reduced the transactional costs of } \\
\text { currency trading and foreign exchange processes. } \\
\text { The service levels of the two main relationship banks } \\
\text { could be compared. Splitting the business also put } \\
\text { the banks' pricing under pressure. More payments } \\
\text { were processed electronically, which benefitted } \\
\text { suppliers in terms of improved cash flow and } \\
\text { improved quality of the payment process. }\end{array}$ \\
\hline
\end{tabular}




\begin{tabular}{|c|c|c|}
\hline 1998 & $\begin{array}{l}\text { Introduced Automated Clearing House (ACH) payment } \\
\text { process. This significantly reduced Motorola's cost to } \\
\text { process payments. Semiconductors division was on } \\
\text { SAP. Motorola moved to Oracle. Some parts of the } \\
\text { company remained on SAP after three years but } 85 \% \\
\text { on Oracle. } \\
\text { Asian Services Centre set up in China to manage and } \\
\text { process all Asian payments. Six sigma techniques were } \\
\text { used to track the operational performance. }\end{array}$ & $\begin{array}{l}\text { The cost for making an } \mathrm{ACH} \text { payment is significantly } \\
\text { lower than an international wire payment. There is } \\
\text { greater consistency in the time taken for suppliers to } \\
\text { receive the funds. } \\
\text { Centralising the treasury process was reasonably } \\
\text { straightforward at Motorola because most of the } \\
\text { manufacturing operations were using the same } \\
\text { version of an ERP system. } \\
\text { The services centre integrates the Oracle } \\
\text { manufacturing platform with the banking systems, } \\
\text { which gives operational advantages in terms of } \\
\text { business process design, data consistency and } \\
\text { accuracy of payments. }\end{array}$ \\
\hline 1999 & Globalised treasury cash management function & $\begin{array}{l}\text { The service provided by the treasury was extended } \\
\text { to Asia. }\end{array}$ \\
\hline 2002 & $\begin{array}{l}\text { Processing errors reduced to the point that all } \\
\text { payments could be paid electronically. }\end{array}$ & $\begin{array}{l}\text { The suppliers benefited from receiving lower value } \\
\text { payments earlier. }\end{array}$ \\
\hline 2003 & $\begin{array}{l}\text { Back office systems and operations were improved } \\
\text { using six sigma methodology, which exploited the } \\
\text { improved accuracy from the new Oracle system. } \\
\text { System enhancements were also carried out during } \\
\text { this period. }\end{array}$ & $\begin{array}{l}\text { Incremental process improvements related to the } \\
\text { Oracle system continued to improve the certainty of } \\
\text { the payment date for suppliers and further improved } \\
\text { the quality of the financial processes. }\end{array}$ \\
\hline 2004 & $\begin{array}{l}\text { Motorola's semiconductor division was demerged and } \\
\text { set up as a separate company. The netting system was } \\
\text { a mainframe system that was included as part of the } \\
\text { newly formed company - a different solution was } \\
\text { therefore required. }\end{array}$ & $\begin{array}{l}\text { The treasury had only eight months to replace the } \\
\text { netting system. }\end{array}$ \\
\hline 2005 & $\begin{array}{l}\text { New netting system was implemented which was } \\
\text { based on an outsourced solution from ABN AMRO. }\end{array}$ & $\begin{array}{l}\text { Outsourcing the netting was the most pragmatic } \\
\text { solution compared to the other two main options. } \\
\text { Renting space on another IBM mainframe was } \\
\text { deemed to be too expensive and also tied Motorola to } \\
\text { old technology, while developing a new version to } \\
\text { run on servers was too expensive and unlikely to be } \\
\text { completed on time. }\end{array}$ \\
\hline 2005 & $\begin{array}{l}\text { With the exception of the U.S. all the third party } \\
\text { payment processing was transferred to China. }\end{array}$ & $\begin{array}{l}\text { An improvement in scale efficiencies was achieved. } \\
\text { In addition, a dedicated specialist team further } \\
\text { reduced errors in the payments and foreign exchange } \\
\text { processes. }\end{array}$ \\
\hline 2005 & $\begin{array}{l}\text { J.P. Morgan was chosen as the sole supplier of payment } \\
\text { processing outside the U.S. }\end{array}$ & $\begin{array}{l}\text { Although Motorola appeared to weaken its } \\
\text { negotiating position in a sole-supply banking } \\
\text { relationship, the arrangement generated operational } \\
\text { benefits because it made it easier to resolve payment } \\
\text { errors and service levels were also improved. }\end{array}$ \\
\hline 2007 & $\begin{array}{l}\text { Major acquisition of Symbol Inc. required the treasury } \\
\text { system to be integrated with SAP in addition to the } \\
\text { existing Oracle system. }\end{array}$ & $\begin{array}{l}\text { The integration with the SAP system required } \\
\text { significantly more effort than Motorola's standard } \\
\text { Oracle ERP system. }\end{array}$ \\
\hline 2008 & European cash management office moved to Poland. & $\begin{array}{l}\text { The basic advantages were to save overhead costs } \\
\text { and also to access skilled staff. }\end{array}$ \\
\hline $\begin{array}{c}1990- \\
2010\end{array}$ & $\begin{array}{l}\text { In total, } 12 \text { release versions of the netting system were } \\
\text { implemented, each one representing significant } \\
\text { operational enhancements. }\end{array}$ & $\begin{array}{l}\text { An incremental process enabled the quality of the } \\
\text { process to be maintained. This was vital because with } \\
\text { only a small treasury staff it would not have been } \\
\text { possible to manually correct errors in a high volume, } \\
\text { high value environment where the payment } \\
\text { processes were time-critical. }\end{array}$ \\
\hline
\end{tabular}

